UCRL-ID-110438

\title{
PROGRAM RELAX \\ A Code Designed to Calculate Atomic Relaxation Spectra of X-Rays and Electrons
}

Dermott E. Cullen

Lawrence Livermore National Laboratory

March 1992

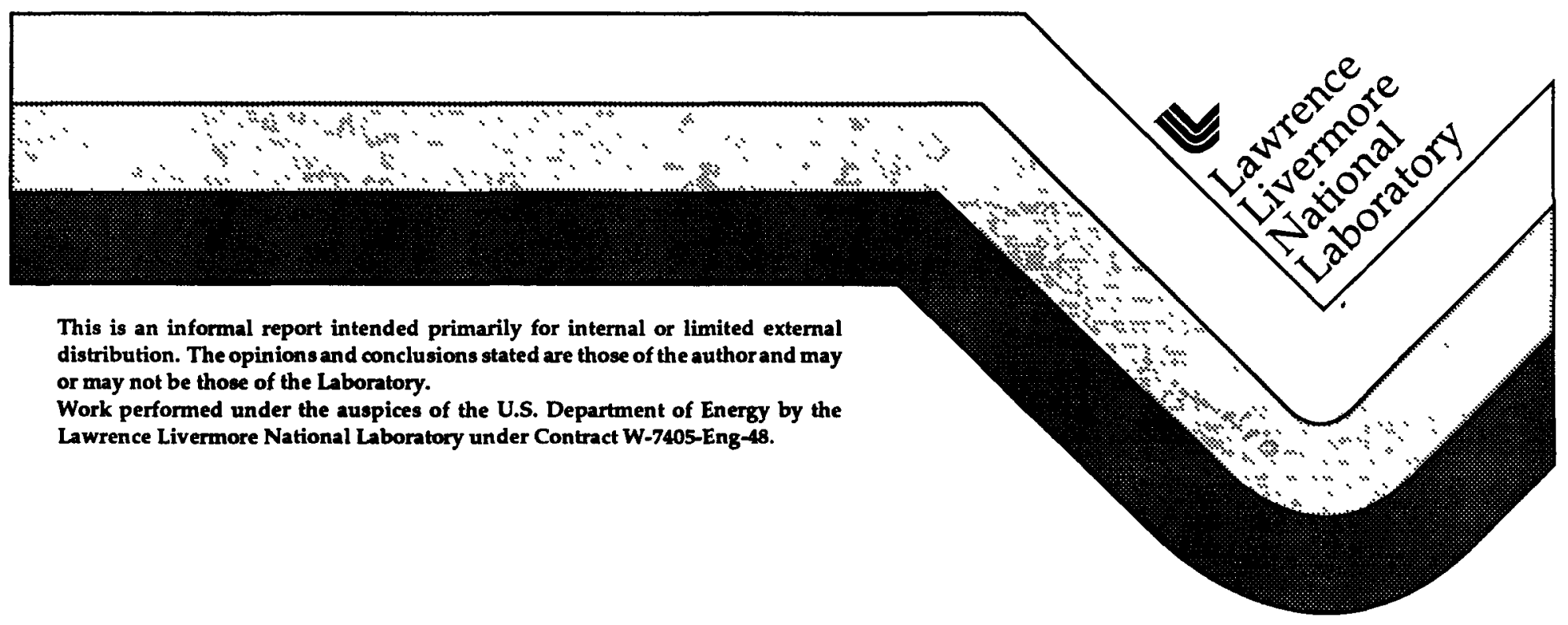




\section{DISCLAIMER}

This report was prepared as an account of work sponsored by an agency of the United States Government. Neither the United States Government nor any agency Thereof, nor any of their employees, makes any warranty, express or implied, or assumes any legal liability or responsibility for the accuracy, completeness, or usefulness of any information, apparatus, product, or process disclosed, or represents that its use would not infringe privately owned rights. Reference herein to any specific commercial product, process, or service by trade name, trademark, manufacturer, or otherwise does not necessarily constitute or imply its endorsement, recommendation, or favoring by the United States Government or any agency thereof. The views and opinions of authors expressed herein do not necessarily state or reflect those of the United States Government or any agency thereof. 


\section{DISCLAIMER}

Portions of this document may be illegible in electronic image products. Images are produced from the best available original document. 


\section{DISCLAIMER}

This document was prepared as an acccount of work sponsored by an agency of the United States Government. Neither the United States Government nor the University of California nor any of their employees, makes any warranty, express or implied, or assumes any legal liability or responsibility for the accuracy, completeness, or usefulness of any information, apparatus, product, or process disclosed, or represents that its use would not infringe privately own rights. Reference herein to any specific commercial products, process, or service by trade name, trademark, manufacturer, or otherwise, does not necessarily constitute or imply its endorsement, recommendation, or favoring by the United States Government or the University of California. The views and opinions of authors expressed herein do not necessarily state or reflect those of the United States Government or the University of California, and shall not be used for advertising or product endorsement purposes.

This report has been reproduced directly from the best available copy.

Available to DOE and DOE contractors from the Office of Scientific and Technical Information P.O. Box 62, Oak Ridge, TN 37831

Prices available from (615) 576-8401, FTS 626-8401

Available to the public from the National Technical Information Service

U.S. Department of Commerce 5285 Port Royal Rd., Springfield, VA 22161 
PROGRAM RELAX

UCRL-ID-110438

A Code Designed to Calculate Atomic Relaxation Spectra of $X$-Rays and Electrons

DE92 013751

\author{
by \\ Dermott E. Cullen \\ Lawrence Iivermore National Laboratory \\ $I-298$ \\ P.O. BOX 808 \\ Iivermore, CA 94550
}

March 20, 1992

Introduction

The code RELAX is designed to calculate atomic relaxation spectra of $X$-rays and electrons due to bound-bound transitions. This calculation is based on

the atomic transition data contained in the Iivermore Evaluated Atomic Data Library (EADI).

The results produced by this code for fluorescence yield $\nabla$. atomic number

(z) have been published in "Tables and Graphs of Atomic Subshell and Relaxation Data Derived from the ILNL Evaluated Atomic Data Iibrary (EADL), $z=1-100 "$, UCRI-50400, Vol. 30, October 31, 1991, Lawrence Livermore National Laboratory.

Code Documentation

This code is designed to be self-documenting, in the sense that the latest documentation for the code is included as comment lines at the beginning of the code. Printed documentation, such as this report, are periodically published and consists mostly of a copy of the comment lines from the beginning of the code. The user should be aware that the comment lines within the code are continuously updated to reflect the most recent status of the code and these comment lines should always be considered to be the most recent documentation for the code and may supercede published documentation, such as this report. Therefore the user is advised to always read the documentation within the actual code.

The remainder of this report consists of a listing of the documentation which appears at the beginning of the REIAX code and example output. The example output is for the $\mathrm{K}$-shell of uranium and includes the output report as well as graphs of the emission spectra. 
Comments from REIAX 
PROGRAM REIAX (INPUT, OUTPUT, TAPE5=INPUT, TAPE6=OUTPUT, TAPE10,

REL00010

1 TAPE11, TAPE12, TAPE14, TAPE15)

REL00020

PROGRAM RELAXX

VERSION 90-1 (DECEMBER 1990)

VERSION 91-1 (NOVTMBER 1991) *UPDATED TO PERFORM CALCULATIONS 2

REL00030

REL00040 SEPARATE WAYS AND INSURE COMPLETE

REL00050

REL00060 NUMBER OF PARTICLES AND ENERGY BAIANCE.

REL00070

REL00080

REL00090

REL00100

WRITTEN BY DERMOTT E. CULIEN

IAWRENCE IIVERMORE NATIONAL IAABORATORY

REL00110

$L-298$

P.O. BOX 808

IIVERMORE, CA 94550

U.S.A.

REL00120

REL00130

REL00140

REL00150

REL00160

TELEPHONE 415-423-7359

REL00170

REL00180

PURPOSE

REL00190

REL00200

THIS PROGRAM IS DESIGNED TO CAICULATE ATOM RELAXATION SPECTRA OE X-RAYS AND EIECTRONS DUE TO BOUND-BOUND TRANSITIONS. THIS CALCUIATION IS BASED ON THE ATOM TRANSITION DATA CONTAINED IN THE IIVERMORE EVALUATED ATOMIC DATA IIBRARY (EADI).

REL00210

REL00220

REL00230

REL00240

REL00250

THE PROGRAM WIII ALSO CALCUIATE THE SPECTRUM OF FREE-BOUND TRANSITIONS ASSUMING THAT THE ATOM WILI REIAX BACK TO IT NEUTRAL GROUND STATE BY FILIING ALL REMAINING ELECTRON HOLES THROUGH TRANSITIONS CAPTURING ELECTRONS DIRECTLY FROM THE CONTINUUM.

REL00260

REL00270

REL00280

REL00290

REL00300

THIS PROGRAM WIIL AISO CAICULATE SUBSHELI AVERAGED VALUES, SUCH AS TOTAL MNERGY TO X-RAYS, ELECTRONS AND EREE-BOUND, AVERAGE

REL00310

REL00320

NUMBER OE EMITTED X-RAYS, ELECTRONS AND EREE-BOUND TRANSITIONS

REL00330

AND AVERAGE ENERGY OE X-RAYS, ELECTRONS AND EREE-BOUND TRANSITIONSREL00340

THE SUM OF THE TOTAT ENERGY TO X-RAYS, EIECTRONS AND FREE-BOUND

REL00350

IS EQUAI TO THE BINDING ENERGY OF THE SUBSHELL IN WHICH THE

REL00360

REL00370

INITIAI VACANCY (HOIE) IS IOCATED. THE DIVISION OF ENERGY BETHEEN REL00380

X-RAYS, ELECTRONS AND EREE-BOUND IS COMPLETELY DEEINED BY THE

REL00390

DATA IN EADL. HOFEVER, THE SPECTRUM OF EREE-BOOND TRANSITIONS

REL00400

IS NOT COMPIETELY DEEINED AND THE ASSUNPTION THAT IS USED GERE

REL00410

WILL CONSERVE THE TOTAL ENERGY OF THE SUM OF ALL FREE-BOUND TRANSITIONS AND PRODUCE THE HARDEST POSSIBLE SPECTRUM WITH THE FEWEST POSSIBLE EMITTED X-RAYS.

REL00420

REI00430

REL00440

REL00450

DESCRIPTION OF EINAL ATOM

REI00460

THIS PROGRAM CAN CAICULATE RESULTS EOR A FINAI ATOM,

$=$ REL00470

REL00480

REL00490

1) NEUTRAI - AS EIECTRONS ARE EJECTED FROM THE ATOMS, HOLES CAN BE EIILED BY ELECTRONS EROM THE CONTINUUM (OUTSIDE THE ATOM). IN THIS CASE TRANSITIONS CAN AITAYS OCCUR, SINCE WE ASSUME THAT AS ELECTRONS IEAVE A SUBSHELL THEY ARE REPLACED BY ELECTRONS UNDERGOING TRANSITIONS FROM ANOTHFR SUBSHEII OR THE CONTINUUM, I.E., TE HAVE AN INEINITE SUPPIY OE ELECTRONS

REL00500

REL00510

REL00520

REL00530

REL00540

REL00550

REL 00560 AVAILABLE. IN THIS CASE THE SET OF EOUATIONS HAS A UNIQUE SOLUTION.

2) ISOLATED - HOLES CANNOT BE FILIED BY ELECTRONS EROM THE CONTINUUM. IN THIS CASE TRANSITIONS BETWEEN SUBSHELLS CAN ONLY OCCUR IF THERE ARE REMAINING ELECTRONS IN THE SUBSHELL FROM WHICH THE ELECTRON IS UNDERGOING A TRANSITION TO FILL A HOLE. IN THIS REL 00570 REL00580 REL00590 REL00600 REL00610 REL00620 REL00630 REL00640 CASE THERE WIIL BE COMPETITION BETWEEN THE VARIOUS REL00650 SUBSHELLS FOR ELECTRON TRANSITIONS FROM ONE SUBSHELIREL00660 
C

TO EILL A HOLE IN ANOTHER SUBSHELL - IN THIS CASE REL00670 THE SET OF EQUATIONS DOES NOT HAVE A UNIQUE SOLUTIONREL00680 - THIS PROGRAM WILI CAICULATE THE SOLUTION THAT REL00690 CORRESPONDS TO THE MAXIMUM ENERGY RADIATED FROM THE REL00700 ATOM BY THE MINIMUM NUMBER OF X-RAYS AND ELECTRON REL00710 BY GIVING PRIORITY TO INNER SUBSHELI TRANSITIONS REL00720 OVER OUTER SUBSHELIS TO DEFINE THE COMPETITION. REL00730

REL00740 ASSUMPTIONS REL00750

1) WE ASSUME THAT THE BINDING ENERGY OF THE NEUTRAL ATOMS IN THEIRREL00770 GROUND STATE IS THE SAME AS THE BINDING ENERGY IN ANY IONIZED REL00780 STATE - THIS ASSUMPTION IS BASED ON THE FACT THAT AS YET OUR DATA BASE - EADI - ONLY CONTAINS A SINGLE BINDING ENERGY TO REL00790 DESCRIBE EACH SUBSHELI - AT THE CURRENT TIME IT IS BEYOND OUR CAPABIIITIES TO PROVIDE MORE EXTENSIVE SETS OF BINDING ENERGY TO DESCRIBE ALL COMBINATIONS OF IONIZED STATES OF EACH ATOM.

2) WE ASSUME AN INITIAL CONDITION OF ONE SUBSHELL OF ONE ELIMNENT TO BE SINGLY IONIZED AND THEN DESCRIBE THE REIAXXATION DUE TO BOUND-BOUND TRANSITIONS. WE DO NOT CONSIDER EXCITED ATOMS AND EADI DOES NOT UNIQUELY DEFINE FREE-BOUND TRANSITIONS.

3) WE ASSUME THAT THE RADIATIVE AND NON-RADIATIVE TRANSITION DATA IS IN UPPER TRIANGIAR FORM BASED ON ASCBNDING SUBSHELL INDEX - I.E., NO TRANSITIONS BETWEEN SUBSHELI I AND SUBSHELL $K$ IF I IS GREATER THAN OR EQUAL TO $\mathrm{K}$. THIS CONDITION IS SATIFIED BY THE ENTIRE EADI DATA BASE AS OF DECFMBER 1990.

ENERGY OF EMITIED X-RAYS AND ELECTRONS

REL00800

REL00810

REL00820

REL00830

REL00840

REL00850

REL00860

REL00870

REL00880

REL00890

REL00900

REL00910

REL00920

REL00930

REL00940

REL00950

REL00960

FOR A RADIATIVE TRANSITION BETWEEN SUBSHELLS I AND $X$ THE ENERGY OF THE EMITTED X-RAY IS DEFINED TO BE,

$=$ REI00970

REI00980

REL00990

REL01000

$E(X-R A Y)=$ B.E. (R) - B.E. (I)

REL01010

B.E.(R) = BINDING ENERGY OF AN ELECTRON IN THE R-TH SUBSHELL B.E.(I) = BINDING ENERGY OF AN ELECTRON IN THE I-TH SUBSHELI

REL01020

REL01030

REL01040

REL01050

FOR A NON-RADIATIVE TRANSITION BETWEEN SUBSHELLS I AND $K$ IN WHICH REL01060 AN ELECTRON IS EMITTED EROM SUBSEELI $J$ THE ENERGY OF THE EMITTED RELO1070 ELECTRON IS DEFINED TO BE,

E(ELECTRON) = B.E. (R) - (B.E. (I) + B.E. (J))

REL01080

REL01090

REL01100

REL01110

UNCERTAINTY IN RESULTS

REL01120

SINCE THERE IS A UNCERTAINTY ASSOCIATED WITH EACH BINDING ENERGY

(B.E.) THERE WILL ALSO BE AN UNCERTAINTY ASSOCIATED WITH THE REL01130 ENERGY OF THE EMITTED X-RAYS AND ELECTRONS. THE UNCERTAINTY IN REL01140 REL01150 1 PER-CENT AND IS MORE FOR IONIZED ATOMS. THIS MEANS THAT FOR REL01180 TRANSITIONS WHERE THE BINDING ENERGIES ARE ALMOST EQUAL THERE WILL BE A RATHER LARGE UNCERTAINTY IN THE EMISSION ENERGY OF THE $X$-RAYS AND ELECTRONS. GENERALLY THIS HILL OCCUR FOR RATHER LOW REL01190 ENERGY X-RAYS AND ELECTRONS, WHERE THE EMISSION ENERGY IS MUCH REL01200 REL01210 REL01220 IESS THAN ANY OF THE BINDING ENERGIES INVOLVED IN THE TRANSITION, REL01230 E.G., FOR RADIATIVE, B.E. (R) AIMOST EQUAL TO B.E.(I), FOR NON-RADIATIVE, B.E. (K) AIMOST EQUAL TO B.E.(I) +B.E. (J) .

REL01240 REL01250 NEGATIVE ENERGY ELECTRONS AND ENERGY RE-BALANCE 

THE NUMBER OF EMITTED X-RAYS AND ELECTRONS.

REL01330

REL01340

REL01350

IN THIS CODE WHEN THE CAICULATED ENERGY OF AN EMITTED ELECTRON RELO1360

IS NEGATIVE THE TRANSITION IS AIIOWED TO PROCEED AND TFE ELECTRON REI01370 IS ASSIGNED AN ENERGY OF EXACTLY ZERO. THIS PROCEDURE RAS BEEN FOUND TO IN AII CASES BE CONSISTENT WITH THE ASSUMED UNCERTAINTY IN THE BINDING ENERGIES, I.E., A CAICUTATED NEGATIVE ELECTRON REI01380 ENERGY REALIY INDICATES THE EMISSION OF A VERY LOW ENERGY ELECTRONRELO1410 WITH A IARGE UNCERTAINTY IN ITS ENERGY - WHICH WE HERE DEFINE TO BE A ZERO ENERGY ELECTRON.

THIS PROCEDURE CAN RESULT IN THE LOSS OF AN ENERGY BATANCE. THE TOTAI ENERGY TO X-RAYS, ELECTRONS CAN BE DEFINED BY SUMAING OVER ALI TRANSITIONS THE PRODUCT OE THE EMISSION ENERGY AND THE REI01470

REL01420 REL01430

REL01440 REI01450 TRANSITION PROBABILITY. SIMILARIY THE TOTAL ENERGY TO IOCAL (EREE-RELO1480 BOUND) CAN BE DEFINED BY SUMMING OVER ALL ELECTRON HOLES THAT R RL01490 REMAIN = THE PRODUCT OF THE BINDING ENERGY AND THE NUMBER OE HOLES IN EACH SUBSHELI. THIS PROCEDURE RESULTS IN AN EXACT ENERGY RELO1510 BAIANCE, EXCEPT IN THE CASE WHERE WE HAVE ASSIGNED ZERO ENERGY TO ELECTRONS HHOSE CALCULATED EMISSION ENERGY IS NLGATIVE.

REL01520

REL01530

REL01540

IN THE CASE WHEN WE ASSIGN ZERO ENERGY TO EIECTRONS THE RUSULT IS THAT THE CACULATED ENERGY BALANCE AS TEE SUM OF THE TOTAL X-RAY, ELECTRON AND IOCAI ENERGIES EXCEEDS THE BINDING ENERGY, I.E., WE DO NOT HAVE AN ENERGY BAIANCE.

TO ACHIEVE AN ENERGY BATANCE WE CAICULATE THE TOTAL ENERGY TO $X$-RAYS AND EIECTRONS AND DEFINE THE IOCAI ENERGY TO BE THE DIFTERENCE BETWEN THIS SUM AND THE BINDING EMERGY. IN ORDER TO HAVE THE CAICULATED IOCAL ENERGY BASED ON REMAINING HOLES AND BINDING ENERGIES BE EQUAL TO THE CAICULATED IOCAL ENERGY BASED ON THE BINDING ENERGY MINOS THE SOM OF THE TOTAL ENERGY TO X-RAYS AND ELECTRONS, WE DEEINE THE ENERGY OE FREE-BOUND TRANSITIONS TO BE SIIGETLY IESS THAN THE BINDING ENERGY, BY AN AMOUNT CORRESPONDING TO THE RATIO OE THE IOCAT ENERGY CAICULATED BY THE TWO METHODS - THUS FORCING AN ENTRGY BATANCE.

GENERATLY WTEN NEGATIVE IMNERGY ELECTRONS OCCUR THE SUM OF THEIR ENERGIES IS ONLY A SMALI FRACTION OI 1 PER-CENT OF THE BINDING ENERGY, I.E., MUCH IESS THAN THE UNCERTAINIY IN THE BINDING ENERGIES. THEREFORE THIS RE-BATANCE PROCEDURE WILI GENERALLY SHIET THE EREE-BOUND EMISSION BNERGIES BY ONLY A SMALI ERACTION OF 1 PER-CENT, MUCH IESS THAN THE UNCERTATNTY IN THE BINDING ENERGY AND AS SUCH OF NO PRACTICAL CONCERN.

NOTE - THIS RE-BATANCE SHOUTD NEVER BE ACHIEVED BY CHANGING THE NUMBER OF REMAINING HOLES IN FACH SUBSHELL, BECAUSE THESE HOLES ARE REQUIRED TO EVENTUALIY RETURN THE ATOM TO EXACT NEUTRAIITY.

THIS ENERGY RE-BAIANCE PROCEDORE, WHICH IS ONLY NECESSARY MHEN USING THE BINDING ENERGIES WOOTD IEAD TO THE EMISSION OF A NON-PHYSICAL NEGATIVE ENERGY EIECTRON, IS CONSISTENT WITH THE RONOWN UNCERTAINTY IN THE BINDING ENERGIES.

REL01550

REL01560

REL01570

REL01580

RIL01590

REL01600

REL01610

REL01620

REL01630

REL01640

REL01650

REL01660

REL01670

REL01680

REL01690

REL01700

REL01710

REL01720

REL01730

REL01740

REL01750

REL01760

REL01770

REL01780

REL01790

REL01800

REL01810

REL01820

REL01830

REL01840

REL01850

REL01860

REL01870

INPUT ENDI FORMAT

REL01880

REL01890

THIS PROGRAM ONLY USES THE ENDI CHARACTER OR CARD IMAGE FORMAT (AS OPPOSED TO THE BINARY FORMAT). THE SOURCE OF AIL EVALUATED DATA USED BY THIS PROGRAM IS THE IIVERMORE EVALUATED ATOMIC DATA LIBRARY (EADI). 


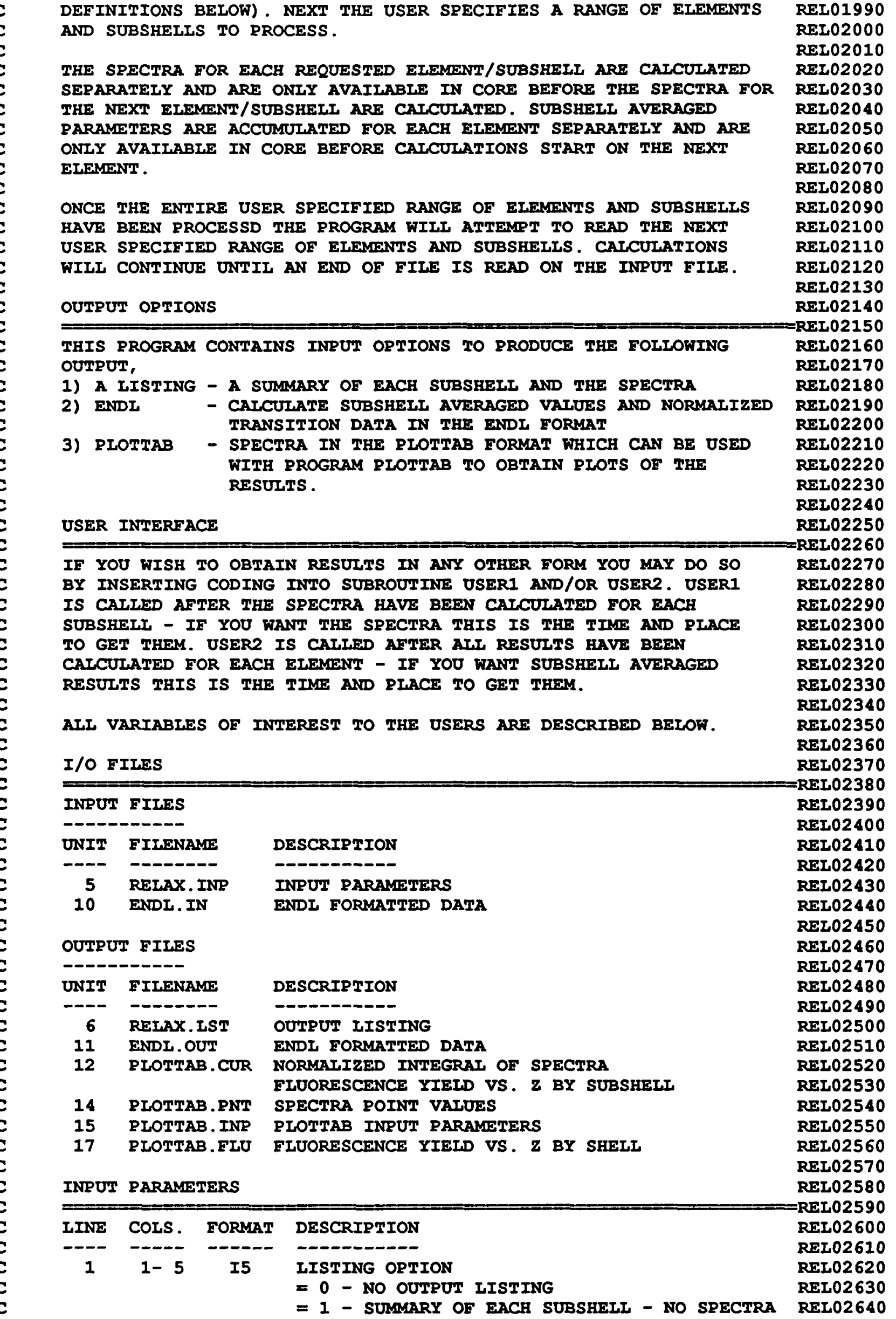




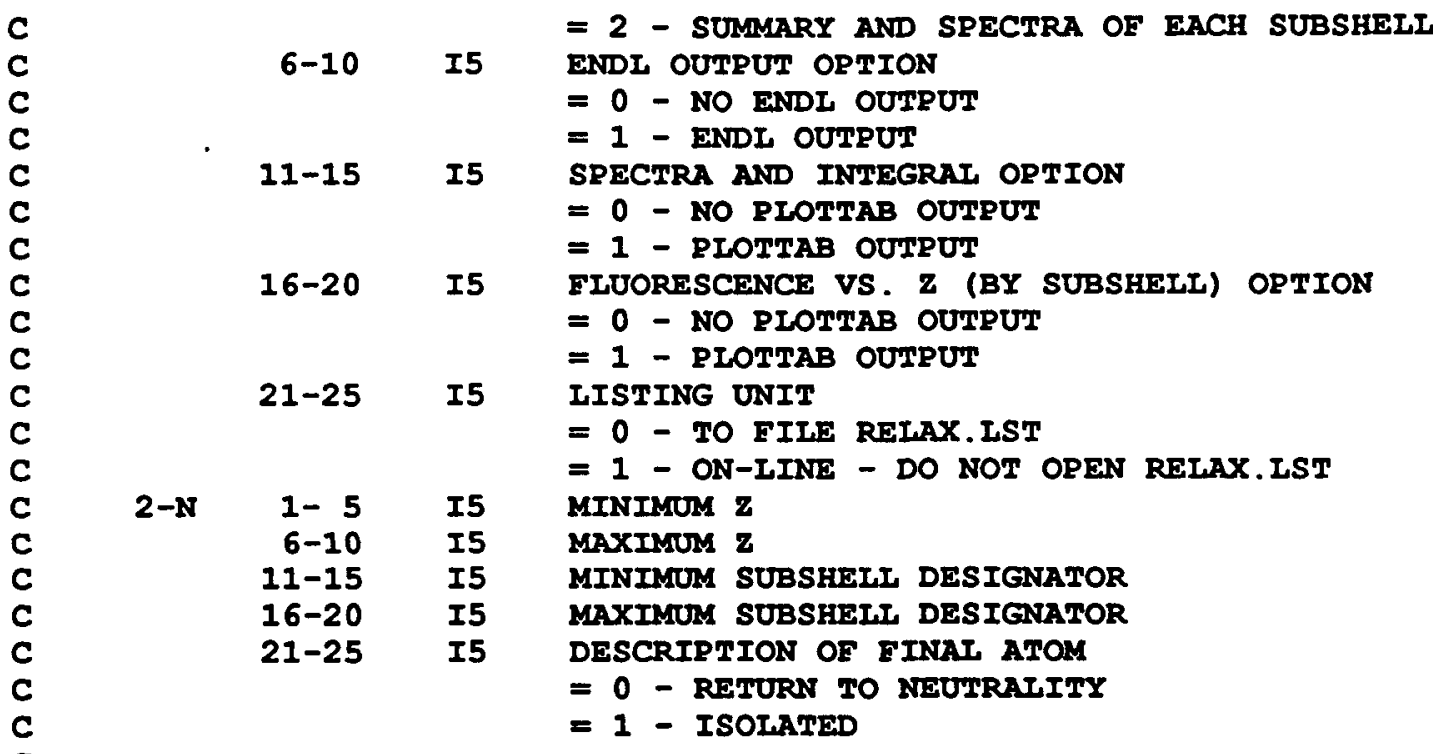

REL02650

REL02660

REL02670

REL02680

REL02690

REL02700

REL02710

REL02720

REL02730

REL02740

REL02750

REL02760

REL02770

REL02780

REL02790

REL02800

REL02810

REI02820

REI02830

REI02840

REI02850

IINE 2 MAY BE REPEATED ANY NUMBER OF TIMES. EACA ELTMENT/SUBSFEIT REI02860 REQUEST WILI BE PROCESSED SEPARATELY AND PROCESSING WIIL CONTINUE REL02870 UNTIL AN END OF FIIE IS READ ON THE INPUT EILE.

REL02880

THE MINIMUM AND MAXIMUM Z MUST BE BETWEEN 1 AND 100 AND THE MAXIMUM MUST BE EQUAT TO OR GRFATER THAN THE MINIMUM. SIMIIARIY THE MINIMUM AND MAXIMUM SUBSFEII DESIGNATORS MUST BE BETWEEN 1 AND 61 AND THE MAXIMUM MUST BE EQUAI TO OR GREATER THAN THE MINIMUM. IF THE INPUT PARAMETERS DO NOT SATISEY THESE CONDITIONS THE PROGRAM WILI TERMINATE EXECUTION.

REL02890

REL02900

REI02910

REL02920

REL02930

REI02940

REI02950

EXAMPIE INPUT NO. 1

PROCESS THE ENTIRE EADL IIBRARY FITH AIL OUTPUT OPTIONS ON. THE FOLLONING 2 INPUT IINES ARE REQUIRED,

$$
\begin{array}{rrrrr}
2 & 1 & 1 & 1 & 0 \\
1 & 100 & 1 & 61 & 0
\end{array}
$$

EXAMPLE INPUT NO. 2

PROCESS THE MAGNESIUM $(\mathrm{z}=12), \mathrm{K}$ SHEIT (SUBSHEIL DESIGNATOR $=1$ ) AND ONLY OUTPUT A EULI IISTING. THE FOILOWING 2 INPUT IINES ARE REQUIRED,

$\begin{array}{rrrrr}2 & 0 & 0 & 0 & 0 \\ 12 & 12 & 1 & 1 & 0\end{array}$

REL02960

REL02970

REL02980

REL02990

REL03000

REL03010

REL03020

REL03030

REL03040

REL03050

REL03060

REL03070

REL03080

REL03090

REL03100

REL03110

REL03120

REL03130

EXAMPLE INPUT NO. 3

PROCESS AII SUBSHELIS OF $z=6$ THROUGH 10 AND 90 THROUGH 100 . OUTPUT A SUMMARY OF EACH SUBSHELI AND PLOTTAB FORMATTED SPECTRA. THE FOLLOWING 3 INPUT LINES ARE REQUIRED,

REL03140

REL03150

REL03160

REL03170

REL03180

REL03190

$$
\begin{array}{rrrrr}
1 & 0 & 1 & 0 & 0 \\
6 & 10 & 1 & 61 & 0 \\
90 & 100 & 1 & 61 & 0
\end{array}
$$

REL03200

REL03210

REL03220

REL03230

DEFINITION OF ENDL SUBSHELI DESIGNATORS

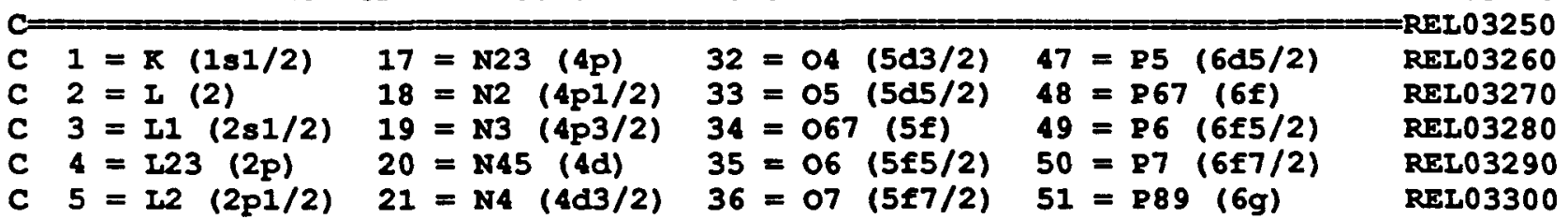




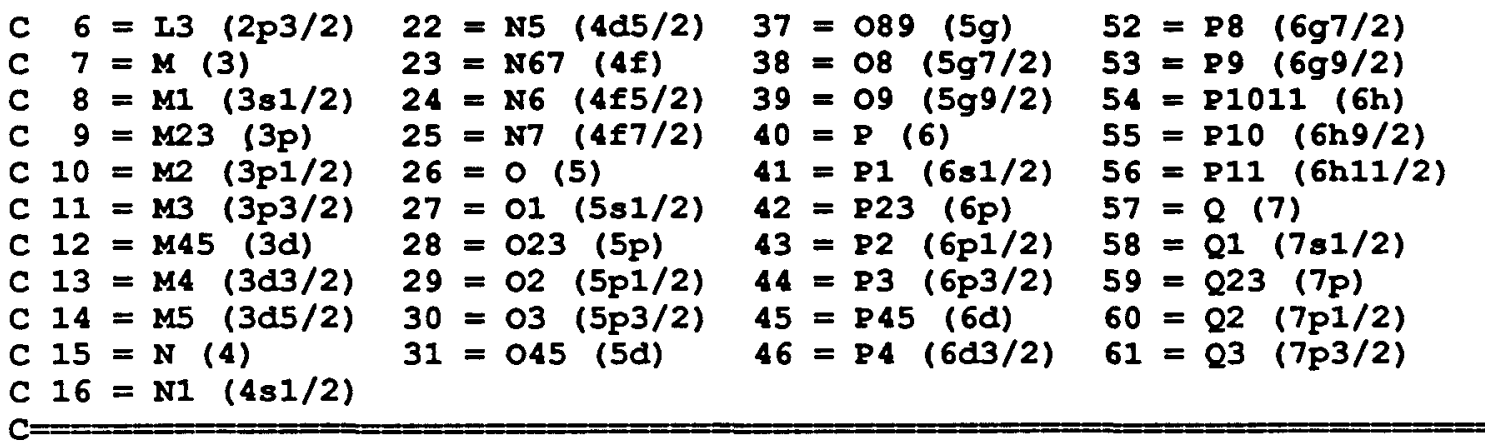

C

C

C

C

C

C

c

C

C

C

C

C

C

C

C

C

C

C

c

C

C

C

C

C

C

C

C

C

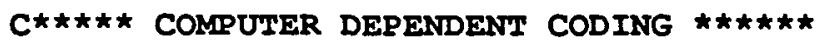

C
DEFINITION OF VARIABLES

BASIS DATA

= 2 FOR ELEMENT (1 TO 100)

MAXSUB = MAXIMUM SUBSHELL INDEX THAT MUST BE USED IN CAICULATION

MAXTRA = MAXIMUM SUBSHEIL INDEX THAT HAS TRANSITIONS TO IT

ATWTGT = ATOMIC WEIGHT OF ELEMENT IZGET

EBMEV = SUBSHELL BINDING ENERGY (MEV)

EBEV = SUBSHELI BINDING ENERGY (EV)

TR = RADIATIVE TRANSITION PROBABIIITIES

TNR = NON-RADIATIVE TRANSITION PROBABILITIES

NSUBR = RADIATIVE TRANSITIONS RFAD FIAG

NSUBN = NON-RADIATIVE TRANSITIONS READ EIAG
REL03310

REL03320

REL03330

REL03340

REL03350

REL03360

REL03370

REL03380

REL03390

REL03400

REL03410

REL03420

REL03430

REL03440

REL03450

REL03460

REL03470

REL03480

REL03490

REL03500

REL03510

REL03520

REL03530

REL03540

REL03550

REL03560

REL03570

REL03580

-REL03590

REL03600

SPECTRA FOR ONE SUBSHELI - CALCUIATED BY THIS CODE

REI03610

REL03620

REL03630

REL03640

REL03650

REL03660

REL03670

REL03680

REL03690

REL03700

NL = NUMBER OF FREE-BOUND TRANSITIONS

REL03710

REL03720

AVERAGE VALUES FOR ALI SUBSHEILS - CAICULATED BY THIS CODE

REL03730

REL03740

REL03750

REL03760

REL03770

REL03780

REL03790

REL03800

REL03810

REL03820

REL03830

REL03840

REL03850

REL03860

REL03870

REL03880

REL03890

REL03900

REL03910

REL03920

REL03930

REL03940

REL03950

REL03960 
(1) DOUBLE/SINGLE TREAT ENERGY DEPENDENT VARIABIES IN SINGLE OR DOUBIE PRECISION. ON IONG WORD LENGTH COMPUTERS (E.G., CRAY)

REL03980 THIS PROGRAM CAN BE OPTIMIZED BY USING SINGLE PRECISION. ON SHORT WORD IENGTH COMPUTERS (E.G., IBM) DOUBIE PRECISION MUST - REPEAT MUST - BE USED IN ORDER TO OBTAIN ACCURATE RESULTS.

(2) CHARACTER/INTEGER 3990

REL04000

REL04010

REL04020

REL04030

REL04040

REL04050

REL04060

AIL CHARACTER VARIABLES ARE TREATED AS CHARACTERS - THE OIDER REL04070 CONVENTION FOR COMPILERS WHICH DID NOT ATIOW CHARACTER TYPE

REL04080 VARIABLES - TREAT ALI AS INTEGERS - IS NOT SUPPORTED IN THIS PROGRAM.

REL04090

REL04100

(3) STOP/EXIT

TERMINATE PROGRAM OSING STOR OR CAII EXIT

REL04110

REL04120

REL04130

(4) SAVE

FORTRAN ORTION TO SAVE ALI VARIABIES BETWEFN SUBROUTINE CAILS - REQUIRED FOR SOME NEWER FORTRAN COMPIIERS

ANY COMBINATION OE THESE OPTIONS CAN BE AUTOMATICALIY TURNED ON ORREL04190 OFF USING PROGRAM CONVERT - CONTACT THE AUTHOR FOR A COPY OF THIS REL04200 PROGRAM.

REL04210

REL04220

REL04230 
This example is for the $\mathrm{K}$-shell of uranium

Only a portion of the listing is included here. The complete listing includes 154 radiative and 2772 non-radiative bound-bound transitions and 10 free-bound transitions. The results have been edited to present here one page of example results for the radiative and non-radiative transitions.

From the enclosed listing we can see that the binding energy of a $\mathrm{K}$-shell electron in uranium is $116.11 \mathrm{keV}$. We can also see that 89.5 \& of this energy will be re-radiated as $x$-rays and most of these $x$-rays will be re-radiated with energies in the range 95 to $116 \mathrm{keV}$ - just below the uranium $\mathbf{K}$-edge, where the photoelectric cross section has a minimum, making these x-rays very penetrating. 
Calculation of X-Ray and Electron Relaxation Spectra (RELAX 91-1)

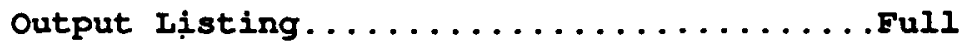

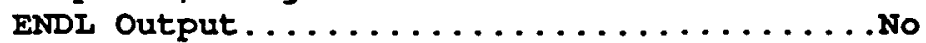

Spectra and Integral................ Yes

Fluorescence Yield $\nabla \mathbf{z}$. $\mathrm{z}$ by Subshell......No

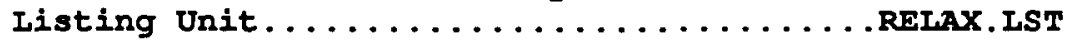

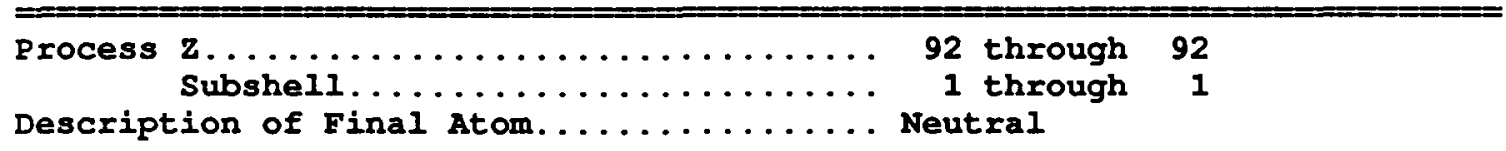

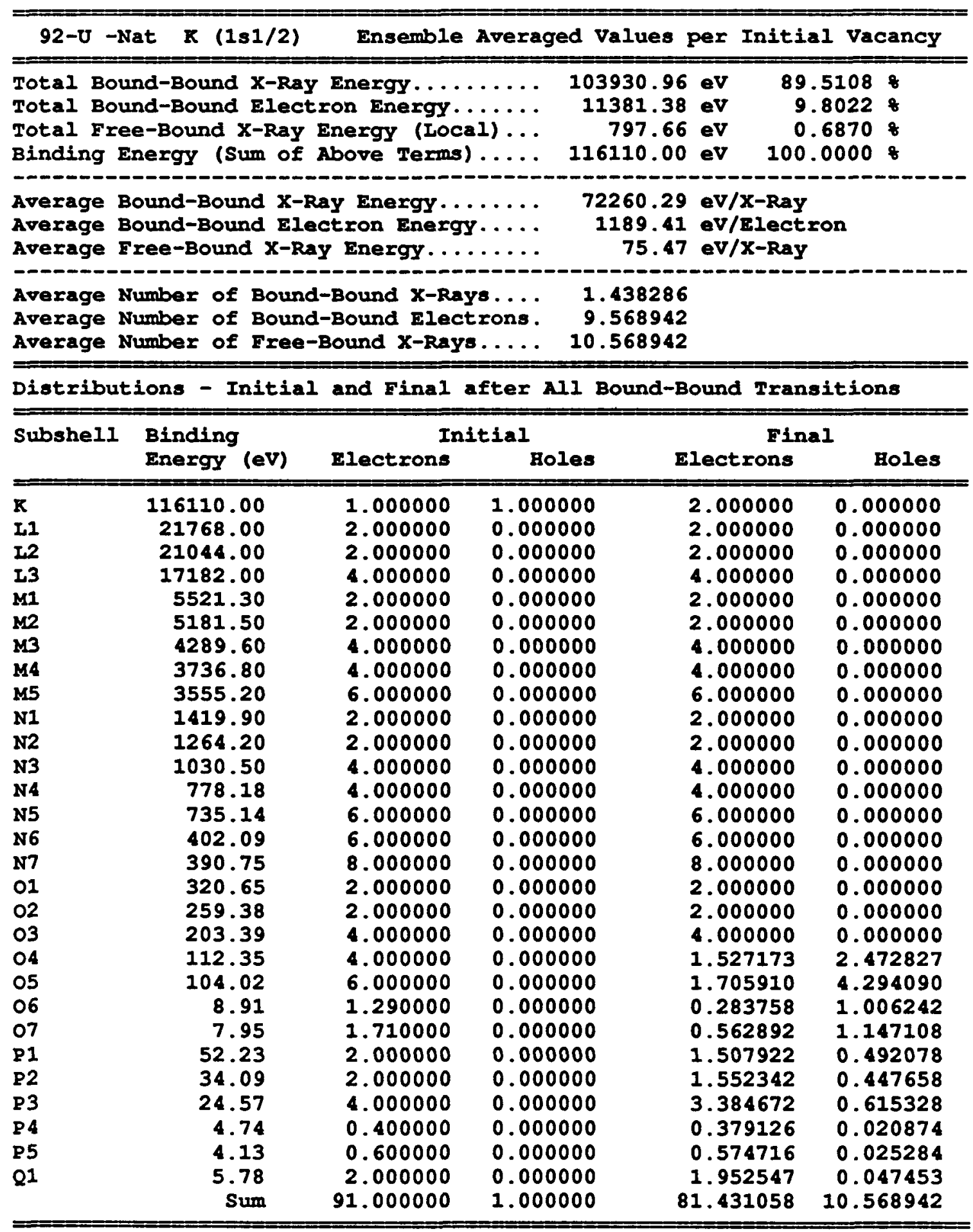




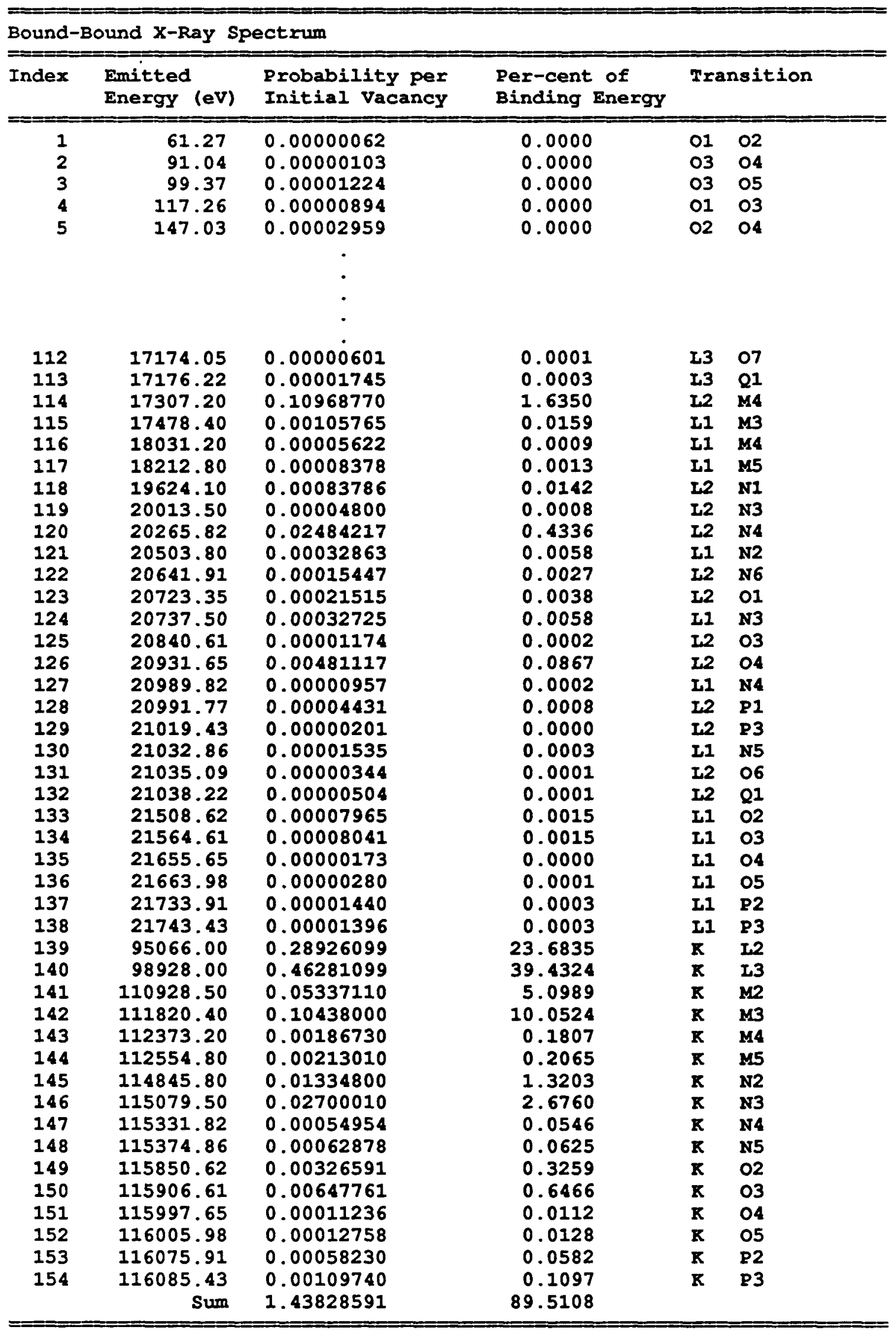




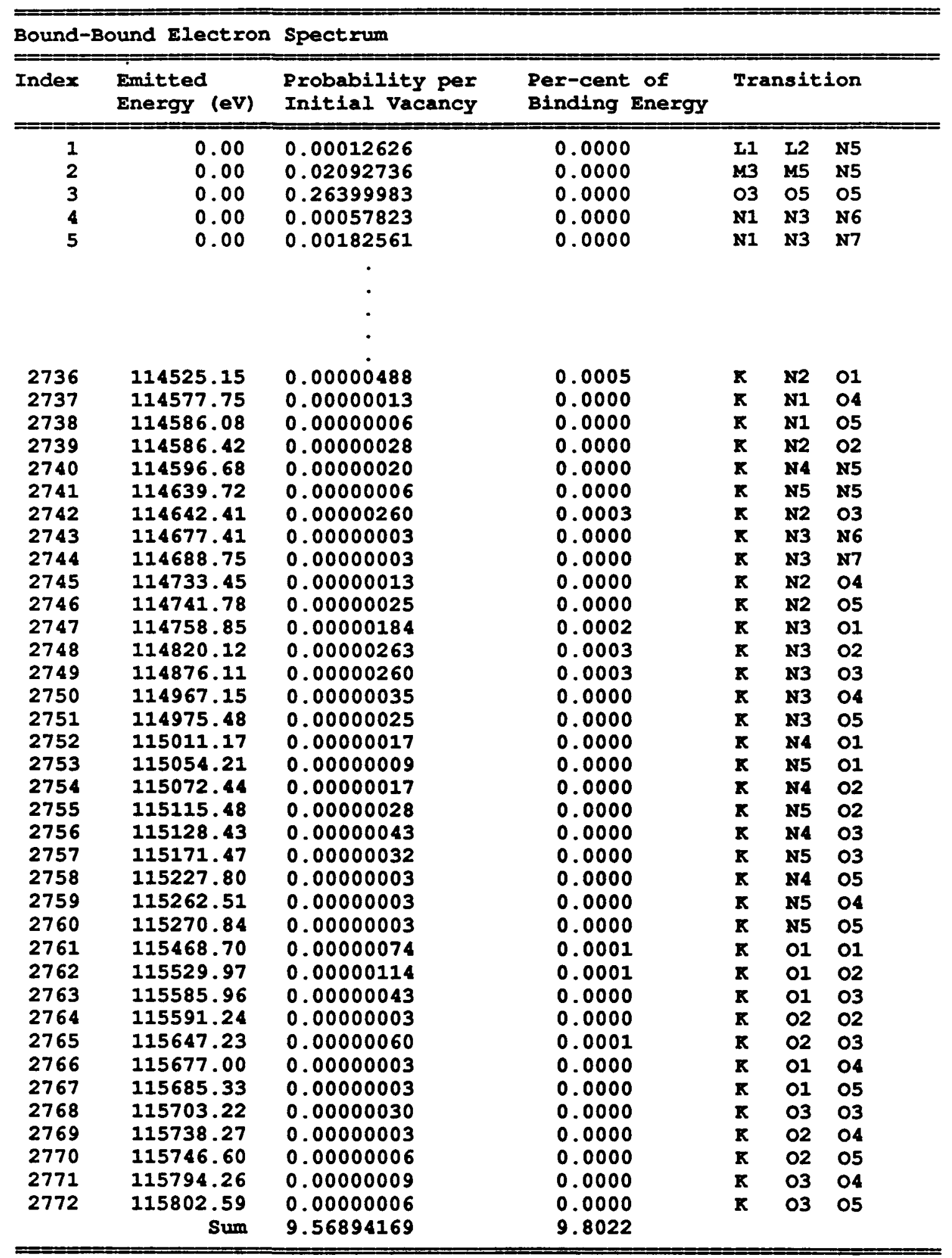




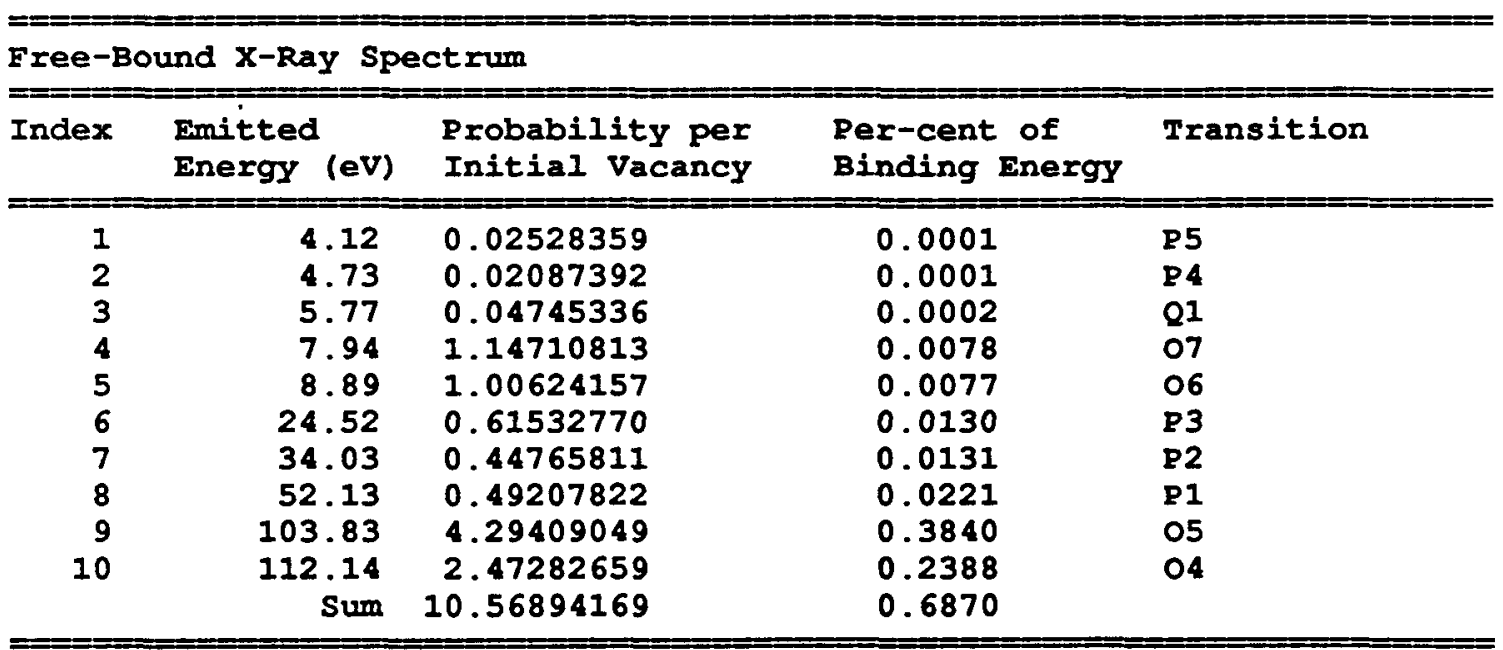

Bound-Bound $X$-Ray and Electron Spectra are based on EADI Relaxation data.

Free-Bound $X$-Ray Spectrum assumes the atom will return to neutrality by electron transitions directly from the continuum to fill all ramaining electron holes, resulting in the emission of $x$-Rays with energy equal to the binding energy of the electron holes. 
This example is for the $\mathrm{K}$-shell of urantum

On these graphs the points represent the emission probability for individual $x$-rays or electrons. The curves represent the integral of the fraction of the binding energy of an electron in the $\mathrm{K}$-shell of uranium.

The legend box identifies the type of emission presented on each graph: x-ray, electron or local, respectively for the three graphs. In addition the legend box defines the fraction of the $\mathrm{K}-\mathrm{shell}$ binding energy included in each spectrum: $x$-rays $89.5 \%$, electrons $9.8 \%$, local $0.68 \%$.

Consider a photon with an energy slightly higher than the binding energy of a $\mathrm{K}$-shell electron in uranium. If this photon undergoes a photoelectric event with a uranium atom, the photon will disappear. An electron will be ejected from the $\mathrm{K}-\mathrm{shell}$ with an energy equal to the difference between the energy of the photon and the binding energy of the electron. Then the atom will relax back to neutrality emitting $x$-rays and electrons with a combined energy equal to the binding energy of a $\mathrm{K}$-shell electron. In this process most (89.5\%) of the energy will be re-emitted as photons (x-rays). The result will be that rather than the initial photon and its energy disappearing (being deposited locally), most of the energy will be re-radiated and can transport a considerable distance. 
Radiative (X-ray) Emission Spectrum

due to a single vacancy in the $K$-shell of uraniun

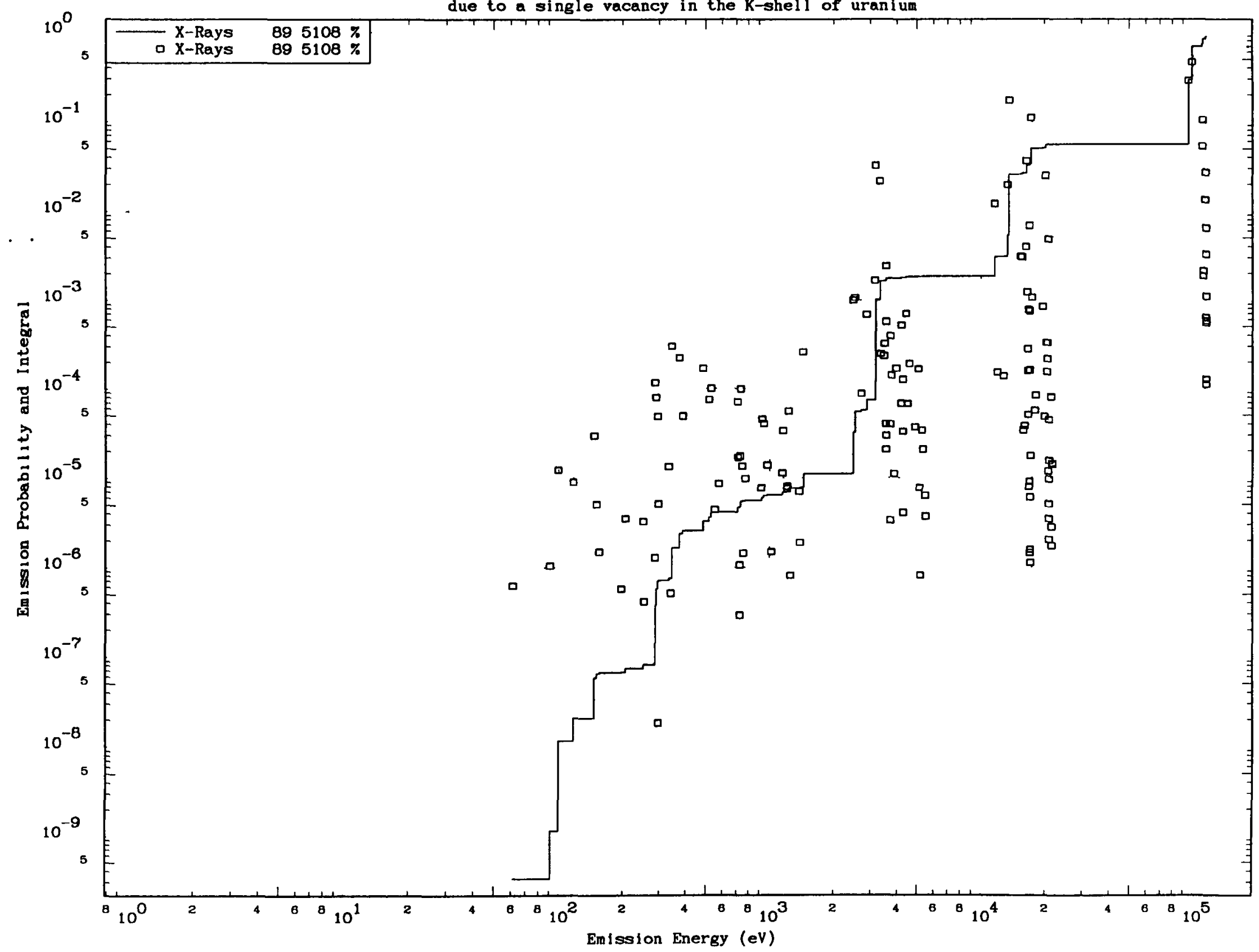




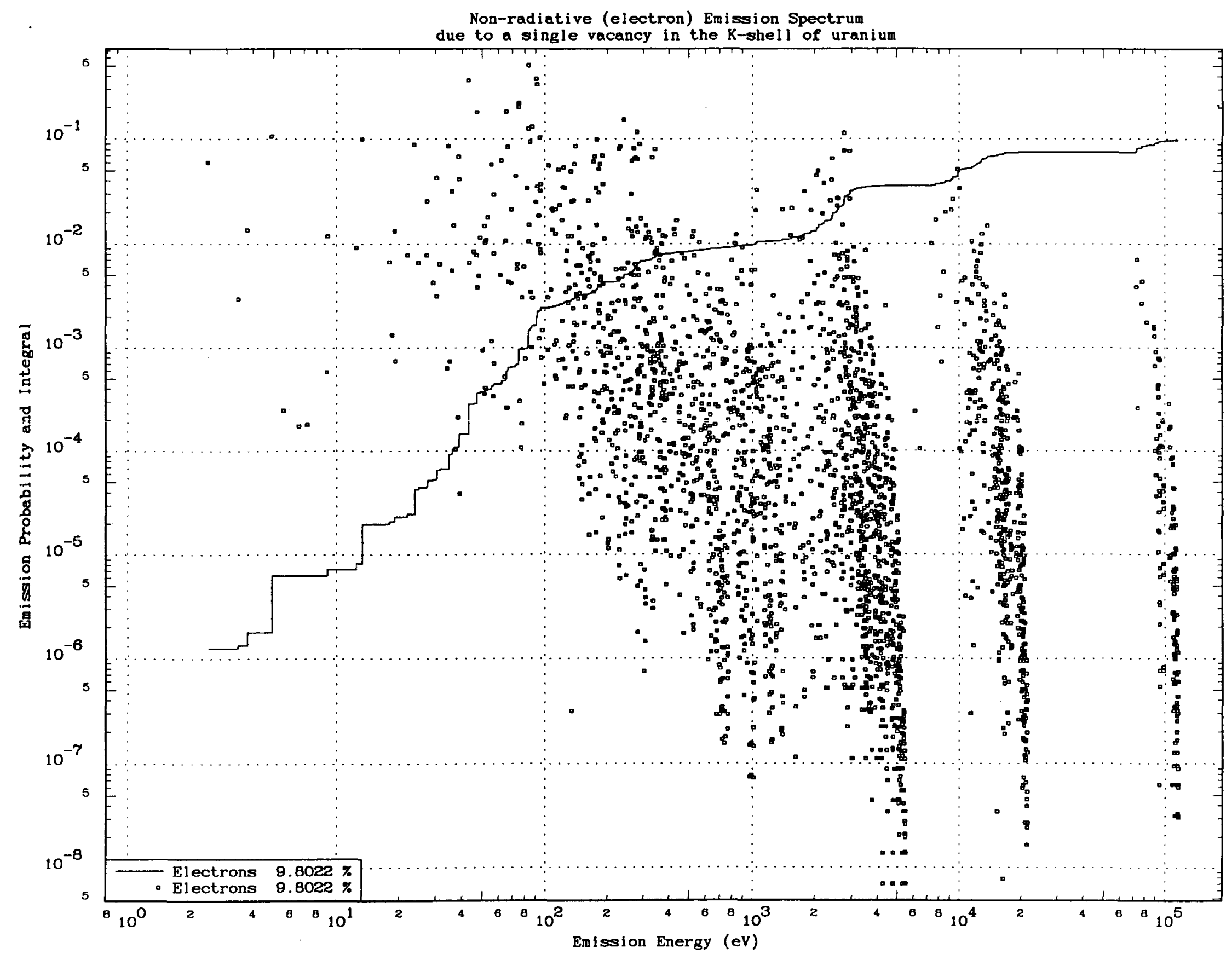


Free-bound (X-ray) Enission Spectrum

due to a single vacancy in the $K$-shell of uraniun

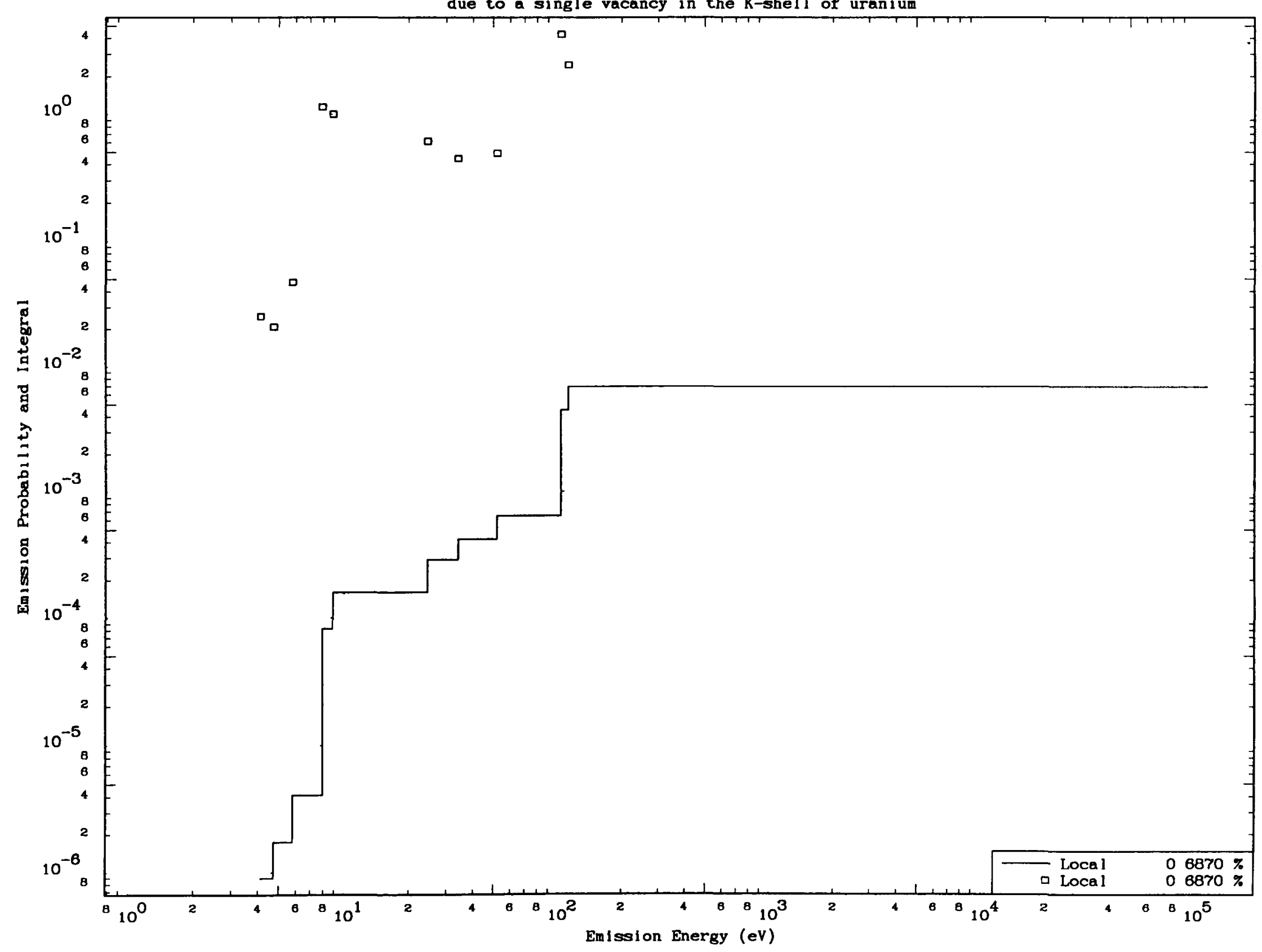


Distribution

S.T. Brandon I-95

R.M. Buck I-45

W.P. Chandlex I-298

M.H. Chen I-296

E.G. Corman I-298

N.T. Dairiki I-298

A.I. Edwards I-298

E. Goldberg I-22

R.J. Howerton I-298

I. KisseI I-59

G.D. Kramer I-22

E.M. Lent L-45

D.F. Patterson I-18

E.F. Plechaty I-298

J.A. Rathkopf I-298

D.A. Resler I-298

J.H. Scofield I-296

P.D. Soran I-16

K.G. Tirsell L-43

P.C. Wheeler I-95

R.M. White I-298

G.B. Zimmerman I-18

A.J. Antolak Sandia National Laboratory, Livermore, CA

C.T. Ballinger Knolls Atomic Power Lab

Box 1072

Schenectady, NY 12301

S.M. Seltzer

Ionizing Radiation Division

Center for Radiation Research

United States Department of Commerce

National Institute of Standards and Technology

Gaithersburg, Maryland 20899 